\title{
Mycobiota of Konya mold-ripened (Kuflu) Tulum cheese and the diversity of Penicillium roqueforti isolates
}

\author{
Meryem SERI ${ }^{1, a}$, Banu METÍN ${ }^{1,2, b, \bigotimes ~}$ \\ ${ }^{1}$ Istanbul Sabahattin Zaim University, Faculty of Engineering and Natural Sciences, Department of Food Engineering, Istanbul; \\ ${ }^{2}$ Istanbul Sabahattin Zaim University, Food and Agricultural Research Center, Istanbul, Turkey. \\ aORCID: 0000-0001-6871-1608; bORCID: 0000-0002-3203-0058. \\ Corresponding author: banu.metin@izu.edu.tr \\ Received date: 11.08.2020 - Accepted date: 27.11.2020
}

\begin{abstract}
Konya Kuflu Tulum cheese is a well-known variety of Turkish mold-ripened cheeses produced by cutting the mature Tulum cheese into pieces to allow the filamentous fungi to grow on its surface in the cool and humid atmosphere in cellars or caves. The aim of the present study was to determine the fungal flora of Kuflu cheese using 54 filamentous fungi and 8 yeasts that were isolated from 26 cheese samples. Internal transcribed spacer (ITS) sequencing indicated that 53 of the mold isolates were Penicillium roqueforti and 1 was Cladosporium cladosporioides. The yeasts were identified as Pichia membranifaciens, Candida zeylanoides, Debaryomyces hansenii, and Geotrichum candidum. Morphological examination of the P. roqueforti isolates on various media revealed similar phenotypes among all but two isolates; however, (GTG)5 fingerprinting analysis indicated that the isolated $P$. roqueforti strains were highly similar in all but one case, which displayed a different pattern. To our knowledge, this study represents the first to conduct molecular methods for identification of fungi associated with Konya Kuflu Tulum cheese. In addition, the morphological and genetic diversities of the Turkey-originated $P$. roqueforti isolates are presented.
\end{abstract}

Keywords: Genetic diversity, (GTG) 5 fingerprinting, Konya Kuflu cheese, morphological diversity, Penicillium roqueforti.

\section{Konya küflü Tulum peynirinin mikobiyotası ve Penicillium roqueforti izolatlarının çeşitliliği}

Özet: Konya Küflü Tulum peyniri, olgunlaştırılmış Tulum peynirinin parçalar halinde kesilerek mağara ve mahzenlerin serin ve nemli atmosferinde peynir yüzeyinin küflendirilmesi ile elde edilen, tanınmış bir Türk küflü peynir çeşididir. Bu çalışmanın amacı, 26 peynir örneğinden izole edilen 54 filamentli fungus ve 8 maya kullanılarak Küflü peynirin fungal florasını belirlemektir. Internal transcribed spacer (ITS) dizilimi, küf izolatlarının 53'ünün Penicillium roqueforti ve 1'inin Cladosporium cladosporioides olduğunu göstermiştir. Mayalar, Pichia membranifaciens, Candida zeylanoides, Debaryomyces hansenii ve Geotrichum candidum olarak tanımlanmıştır. P. roqueforti izolatlarının çeşitli besiyerleri üzerindeki morfolojik incelemesi, iki izolat dışında tüm izolatlarının benzer fenotipleri olduğunu ortaya çıkarmıştır; bununla birlikte, $(\mathrm{GTG})_{5}$ parmak izi analizi, izole edilmiş $P$. roqueforti suşlarının, farklı bir patern sergileyen biri hariç, oldukça benzer olduğunu göstermiştir. Bilindiği kadarıyla, bu çalışma Konya Kuflu Tulum peyniri ile ilişkili küflerin tanımlanmasında moleküler yöntemler uygulayan ilk çalışmayı temsil etmektedir. Ayrıca, Türkiye menşeli $P$. roqueforti izolatlarının morfolojik ve genetik çeşitliliği sunulmuştur.

Anahtar sözcükler: Genetik çeşitlilik, (GTG)5 parmak izi, Konya Küflü peyniri, morfolojik çeşitlilik, Penicillium roqueforti.

\section{Introduction}

Kuflu cheese is a popular variety of traditional Turkish mold-ripened cheese produced in Konya and its surrounding areas (23). The cheese is made largely from skimmed or partially skimmed, raw sheep or goat milk $(16,27)$. After the milk has been allowed to coagulate using rennet, the liquid is drained using a fabric bag to collect the curd. The curd is then cut into pieces, salted, and packed tightly into Tulum bags made of goat skin to ripen for $\sim 3$ months in caves or cellars at $6-12^{\circ} \mathrm{C}$ and 80
$90 \%$ relative humidity, which is the traditional method of production in artisanal facilities $(16,27)$. In others, plastic bags are used and the cheese is ripened in cold storage rooms at $4^{\circ} \mathrm{C}(14,27)$. After ripening, the cheese is cut into 5 - to 6 -cm blocks and left to ripen again in caves, cellars, or rooms until blue-green mold growth can be seen (16, 29). The fungal growth on the cheese is spontaneous and is composed natural flora $(14,16)$.

Blue cheeses of different varieties, such as Roquefort, Gorgonzola, Stilton, Cabrales, and Danablue, 
are produced worldwide $(5,13)$. Penicillium roqueforti is the principal filamentous fungal species associated with blue cheeses and is an important component for the formation of the cheese's characteristic color, flavor, and texture (20). This species is used either as a mold starter or predominates spontaneously on the cheese while it ripens in caves or cellars (5). Substantial morphological, genotypic and functional diversity has been detected among $P$. roqueforti isolates $(7,12)$. Strain-level differences are not only important in the formation of the typical characteristic product but also to develop starter cultures for industrial cheese production.

The filamentous fungi associated with Kuflu cheese was identified in a limited number of studies using only morphological techniques $(6,16,23)$. In addition, the isolated fungi have not been investigated in terms of genotypic diversity. In the present study, the fungi associated with Kuflu cheese were identified using molecular evidence. The morphological diversity of the $P$. roqueforti isolates were analyzed using different media, and their genetic diversity was assessed using (GTG) repetitive element polymerase chain reaction (rep-PCR).

\section{Materials and Methods}

Cheese samples: Twenty-six mold-ripened cheese samples were obtained from different stores and bazaars in Konya in September-October 2018. The cheeses were kept refrigerated until analyses, which were conducted within 1 week at most. This period did not cause fungal viability loss in any cheese sample.

Sample preparation: A 10 -g cheese sample was homogenized in $90 \mathrm{~mL} 2 \%$ sodium citrate buffer ( $\mathrm{pH} 7.5$; Sigma-Aldrich, St. Louis, MO, USA, S4641) using a Stomacher (Bagmixer 400, Interscience, Saint Nom, France) (2).

Isolation of fungi: Serial dilutions from the cheese homogenate were prepared in 1/4 Ringer's solution (Merck KGaA, Darmstadt, Germany, 115525) and inoculated on potato dextrose agar (PDA, Biolife, Milano, Italy, L001929) $(2,15)$. After $4-5 \mathrm{~d}$ at $25^{\circ} \mathrm{C}$, morphologically different yeasts and molds that appeared on the plate were streaked onto new PDA plates. This step was repeated twice for purification. For long-term storage, the fungi were stored in yeast extract peptone dextrose broth (YPD; $10 \mathrm{~g} / \mathrm{L}$ yeast extract [Sigma-Aldrich, Y1625], $20 \mathrm{~g} / \mathrm{L}$ peptone [Merck, 107212], and $20 \mathrm{~g} / \mathrm{L}$ dextrose [Sigma-Aldrich, 16301]) containing 20\% glycerol at $80^{\circ} \mathrm{C}$.

DNA extraction: For DNA isolation, the PureLink Genomic DNA Mini Kit (Thermo Fisher Scientific, St. Louis, MO, USA, K182002) was used with some modifications. First, molds were grown in $20 \mathrm{~mL}$ YPD broth at $25^{\circ} \mathrm{C}$ and $115-120 \mathrm{rpm}$ until visible growth for 1$2 \mathrm{~d}$ using the SI-300R Lab Companion shaker incubator
(Jeio Tech, Inc, Des Plaines, IL, USA). Approximately $200 \mathrm{mg}$ filtered fungal mass was mixed with $200 \mathrm{mg}$ glass beads $(0.1 \mathrm{~mm}$ in diameter; Next Advance, Troy, NY, USA, GB01) in $400 \mu \mathrm{L}$ TEN buffer $(40 \mathrm{mM}$ Tris- $\mathrm{HCl} \mathrm{pH}$ 8.0 [Sigma-Aldrich, T1503], $1 \mathrm{mM}$ ethylenediaminetetraacetic acid [EDTA, Sigma-Aldrich, E4884], $150 \mathrm{mM} \mathrm{NaCl}$ [Isolab Laborgeräte $\mathrm{GmbH}$, Eschau, Germany, 969.036]) (28). The mixture was then homogenized using TissueLyser LT (Qiagen, Hilden, Germany) with four successive operations of $2 \mathrm{~min}$ at 50 $\mathrm{Hz}$ and 2 min waiting on ice, after which $10 \mu \mathrm{L}$ proteinase $\mathrm{K}(20 \mathrm{mg} / \mathrm{mL}$, Thermo Fisher Scientific, EO0491) and $100 \mu \mathrm{L} 10 \%$ SDS (Merck, 817034) were added to the homogenate, and the mixture was incubated at $55^{\circ} \mathrm{C}$ for 60 min using the MTH-100 Thermo Shaker Incubator (Hangzhou-Miu Instruments Co. Ltd., Zhejiang, China) (28). After incubating, $20 \mu \mathrm{L}$ RNase A $(10 \mathrm{mg} / \mathrm{mL}$, Thermo Fisher Scientific, EN0531) was added and the mixture was incubated again at room temperature (22$23^{\circ} \mathrm{C}$ ) for $20 \mathrm{~min}(28)$. The tubes were then centrifuged at $15000 \mathrm{rpm}$ for $10 \mathrm{~min}$ using the Microfuge 20R (Beckman Coulter, Inc., Brea, CA, USA). The supernatant was transferred into a clean microcentrifuge tube and the same amounts of binding buffer from the kit and 96\% ethanol (Merck, 159010) were added. After the mixture was transferred into the kit columns, the manufacturer's protocol was followed. The pure DNA was eluted with 70 $\mu \mathrm{L}$ elution buffer included with the kit. To isolate the DNA from the yeasts, cultures were grown in 10-mL YPD broth in glass tubes and incubated at $25^{\circ} \mathrm{C}$ for $1 \mathrm{~d}$. After centrifugation at $13000 \mathrm{rpm}$ for $10 \mathrm{~min}$, the cell pellet was resuspended in $400 \mu \mathrm{L}$ TEN buffer and the same protocol for filamentous fungi was followed.

The concentration and purity of the isolated DNA were evaluated using the BioSpec Nano spectrophotometer (Shimadzu, Kyoto, Japan).

Polymerase chain reaction and agarose gel electrophoresis: To identify the fungi, universal fungal primers ITS1 (5'-TCCGTAGGTGAACCTGCGG-3') and ITS4 (5'-TCCTCCGCTTATTGATATGC-3') were used (10). The PCR reaction was set up using the following protocol: $1 \mathrm{X}$ buffer, $0.2 \mathrm{mM}$ deoxynucleoside triphosphates (dNTP) mix, $2.0 \mu \mathrm{L} 10 \mathrm{mM}$ forward primer, $2.0 \mu \mathrm{L} 10 \mathrm{mM}$ reverse primer, $\sim 50 \mathrm{ng}$ template DNA, 2.5 U Dream Taq DNA polymerase (Thermo Fisher Scientific, EP0702), and water added to a volume of 50 $\mu \mathrm{L}$. DNA was amplified using the T100 Thermal Cycler (Bio-Rad Laboratories, Hercules, CA, USA) under the following conditions: first denaturation of $1 \mathrm{~min}$ at $94^{\circ} \mathrm{C}$, 34 cycles of denaturation $\left(94^{\circ} \mathrm{C}\right.$ for $\left.30 \mathrm{~s}\right)$, annealing $\left(52^{\circ} \mathrm{C}\right.$ for $30 \mathrm{~s})$, extension $\left(72^{\circ} \mathrm{C}\right.$ for $\left.1 \mathrm{~min}\right)$, and a final extension of $10 \mathrm{~min}$ at $72^{\circ} \mathrm{C}$. 
ITS PCR reactions were purified using the GeneJet PCR purification kit (Thermo Fisher Scientific, K0701) according to manufacturer's instructions and were subjected to Sanger sequencing.

The genetic diversity of the $P$. roqueforti isolates was investigated using rep-PCR fingerprinting with (GTG) primer (5'-GTGGTGGTGGTGGTG-3'). The PCR protocol used was the same as that for ITS PCR except that $4.0 \mu \mathrm{L}$ single primer $\left([\mathrm{GTG}]_{5}(10 \mathrm{mM})\right.$ was used. The PCR conditions were as follows: first denaturation of at $95^{\circ} \mathrm{C}$ for $7 \mathrm{~min}$, followed by 30 cycles of denaturation at $90^{\circ} \mathrm{C}$ for $30 \mathrm{~s}$, annealing at $40^{\circ} \mathrm{C}$ for $1 \mathrm{~min}$, extension at $65^{\circ} \mathrm{C}$ for $8 \mathrm{~min}$, and a final extension at $65^{\circ} \mathrm{C}$ for $16 \mathrm{~min}$ (17). Fingerprinting reactions were run on $0.8 \%$ agarose gel at $35 \mathrm{~V}$ for $\sim 5 \mathrm{~h}$ and visualized using the Gel Doc EZ Imager (Bio-Rad Laboratories, Hercules, CA, USA).

Phylogenetic tree construction: The phylogenetic tree of the ITS sequences of the $P$. roqueforti isolates was constructed using the maximum likelihood method and the Kimura 2-parameter model (18). Evolutionary analysis was conducted using MEGA X with 1000 bootstraps (https://www.megasoftware.net/) (18).

Morphology analysis of $P$. roqueforti isolates: The morphological diversity of the $P$. roqueforti isolates was investigated using PDA, yeast extract sucrose (YES) agar (20 g/L yeast extract [Biolife, 4122202], $150 \mathrm{~g} / \mathrm{L}$ sucrose [Sigma-Aldrich, S0389], $0.5 \mathrm{~g} / \mathrm{L} \mathrm{MgSO}_{4} .7 \mathrm{H}_{2} \mathrm{O}$ [Sigma-
Aldrich, 63138], $1 \mathrm{~mL} / \mathrm{L}$ trace element stock solution [5 $\mathrm{g} / \mathrm{L} \quad \mathrm{CuSO}_{4} .5 \mathrm{H}_{2} \mathrm{O}$, Sigma-Aldrich, C8027], $1 \mathrm{~g} / \mathrm{L}$ $\mathrm{ZnSO}_{4} .7 \mathrm{H}_{2} \mathrm{O}$ [Sigma-Aldrich, Z0251], and $20 \mathrm{~g} / \mathrm{L}$ agar [Sigma-Aldrich, A1296]) and malt extract agar (MEA) (30 g/L malt extract [Merck, 105391], $3 \mathrm{~g} / \mathrm{L}$ peptone [Merck, 107212], 15 g/L agar [Sigma-Aldrich, A1296]), and oatmeal agar (OA, Sigma-Aldrich, O3506) $(8,32)$. The isolates were assigned codes according to their colors on PDA using a color chart as a reference (25).

\section{Results}

Fungal diversity of Konya mold-ripened Tulum cheese: Fifty-four filamentous fungi and 8 yeasts were isolated from 26 cheese samples. ITS sequencing resulted in the identification of 53 of the filamentous fungal isolates as $P$. roqueforti and 1 as $C$. cladosporioides with a BLAST identity score of $100 \%$ (Table 1). In addition, four of the yeasts were identified as $P$. membranifaciens, two as C. zeylanoides, one as D. hansenii, and one as $G$. candidum (Table 1).

A phylogenetic tree was constructed with the ITS sequences of the reference type strains of Penicillium species closely related to $P$. roqueforti, namely, $P$. paneum, P. carneum, and $P$. psychrosexualis. All $P$. roqueforti isolates were clustered together with the $P$. roqueforti-type strain CBS $221.30^{\mathrm{T}}$ (Figure 1).

Table 1. Identification of fungi from Konya mold-ripened Tulum cheese.

\begin{tabular}{lll}
\hline Number of isolates & Identified species & $\begin{array}{l}\text { GenBank number of the reference internal } \\
\text { transcribed spacer sequence }\end{array}$ \\
\hline 53 & Penicillium roqueforti & KM115117 \\
1 & Cladosporium cladosporioides & AY213640 \\
4 & Pichia membranifaciens & NR_111195 \\
1 & Debaryomyces hansenii & NR_120016 \\
2 & Candida zeylanoides & NR_131278 \\
1 & Geotrichum candidum & MH443758 \\
\hline
\end{tabular}
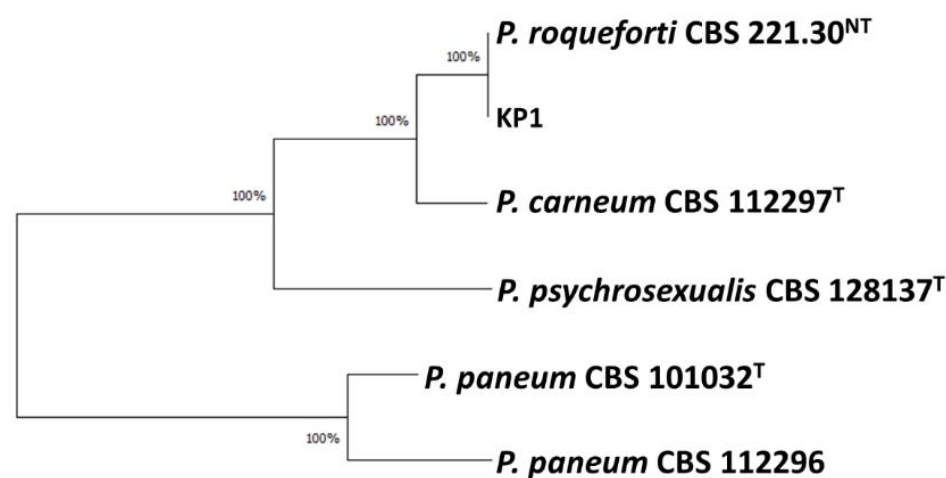

Figure 1. Phylogenetic analysis of the Penicillium roqueforti isolates. All isolates contained the same sequence; therefore, only the KP1 sequence is shown for simplification. The tree was constructed using the following reference sequences of closely related species: $P$. roqueforti CBS 22130 ${ }^{\mathrm{NT}}$ (NR_103621), $P$. carneum CBS $112297^{\mathrm{T}} \quad(\mathrm{NR} 11 \overline{11551)}, \quad P$. psychrosexualis CBS $128137^{\mathrm{T}}\left(\mathrm{NR} \_111552\right), \quad P$. paneum CBS $101032^{\mathrm{T}}$ (NR_103620), and $P$. paneum CBS 112296 (HQ442339). In the final dataset, there were 465 positions, and the analysis involved 6 nucleotide sequences. The tree with the highest $\log$ likelihood (-765.89) is shown. Percentages show the ratio of trees in which the associated taxa were clustered together. Branch lengths were measured using the number of substitutions per site. 


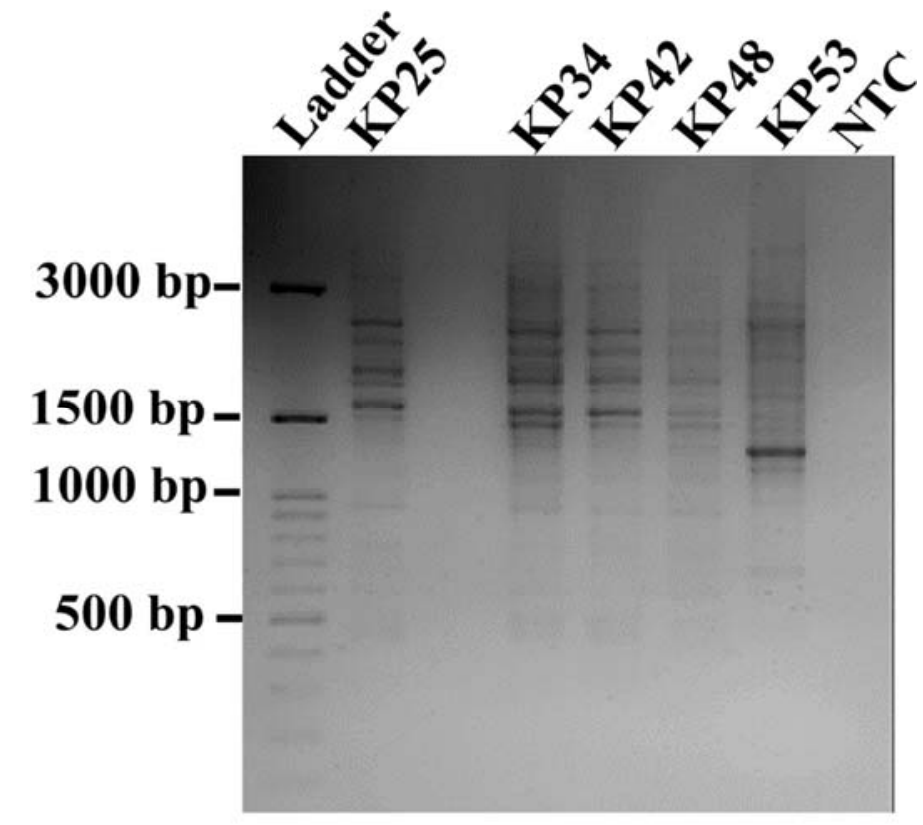

Figure 2. (GTG) 5 repetitive element polymerase chain reaction (rep-PCR) profiles of selected Penicillium roqueforti isolates. KP53 had a pattern different from that of the rest of the $P$. roqueforti isolates, as representatives $\mathrm{KP} 25, \mathrm{KP} 34, \mathrm{KP} 42$, and KP48 are given.

Notes: NTC = no template control in which water is used instead of DNA.

(A)

(B)

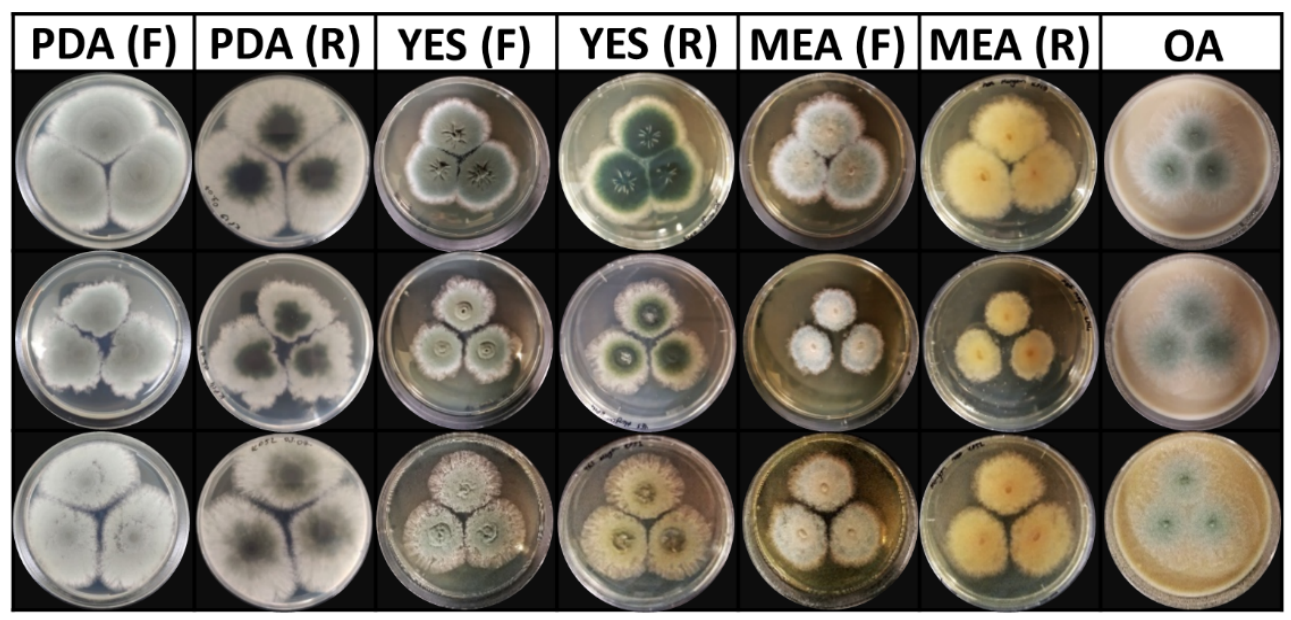

Figure 3. Morphologies of the following three representative Penicillium roqueforti isolates: KP19 (A), KP14 (B), and KP52 (C) on PDA, YES agar, MEA, and OA. Forward (F) and reverse (R) sides of the petri dishes are shown for all media except OA, which is very thick and not suitable for back-side appearance.

Morphological diversity of $P$. roqueforti isolates: The morphological features of the $53 P$. roqueforti isolates were examined using PDA, YES agar, MEA, and OA. The isolates were mostly similar showing absinthe green on PDA according to the color chart (25) (Figure 2). Two isolates were different from the others-KP52 showed a lighter color on all media (viridine green on PDA, (25)), and KP14 had an irregular growing pattern with no difference in color from the others. The results were consistent for two different inoculations conducted at different times (data not shown).

(GTG) $)_{5}$ rep-PCR analysis of genetic diversity of $P$. roqueforti isolates: (GTG) $)_{5}$ rep-PCR conducted on $53 P$. roqueforti isolates resulted in highly similar electrophoretic patterns in all isolates except KP53. Figure 3 shows the electrophoretic pattern in isolate KP53 that is different from that of the rest of isolates, for which four representative patterns are shown. The different pattern of KP53 was reproducible and confirmed by different PCRs (data not shown).

\section{Discussion and Conclusion}

Few studies have investigated the mycobiota of Konya Kuflu cheese. Demirer (6) has isolated filamentous fungi from 10 Konya Kuflu cheese samples and identified all as $P$. roqueforti using morphological techniques. Using similar techniques, Özkalp and Durak (23) have found Penicillium (87.16\%) to be the dominant mold microflora in 140 Konya Kuflu cheese samples and that the dominant species was $P$. roqueforti (42.91\%). Hayaloglu and Kirbag (16) have isolated 158 molds from 30 Kuflu cheese samples and identified their morphological characteristics 
and pigments; however, unlike the results of previous studies, most of the isolated filamentous fungi were observed to be $P$. commune $(10.1 \%)$, followed by $P$. verrrucosum $(9.5 \%)$ and $P$. roqueforti $(8.9 \%)$. In the present study, we used ITS sequencing to identify the fungi species, and 53 out of 54 isolates were determined to be $P$. roqueforti $(98.1 \%)$. Although this finding is more consistent with that of Demirer (6), two later studies found lower percentages of $P$. roqueforti $(16,23)$. Because starter cultures are not used in the production of Kuflu cheese, filamentous fungal profiles could be changing over time, especially according to the mycobiota of the cellars/caves in which the cheeses are ripened. The only isolate we found other than $P$. roqueforti was $C$. cladosporioides, which is a contaminant that can be found in cheeses (16).

In some cheese samples, we observed heavy growths of yeasts on PDA together with the filamentous fungi. These yeasts were isolated and identified as $P$. membranifaciens, C. zeylanoides, and D. hansenii in addition to the filamentous yeast $G$. candidum. Although yeasts of Konya Kuflu Tulum cheese had not been identified, there are reports of yeasts of other Tulum cheeses. In these studies, while $D$. hansenii was observed to be the most common yeast $(21,22), C$. zeylanoides and G. candidum have also been reported $(22,33)$. Yeasts are an important component of the microbiota in blue cheeses and contribute to the production of their characteristic aroma, making them candidates of adjunct cultures $(1,30)$.

In this study, $P$. roqueforti isolates were further investigated using both morphological methods and $(\mathrm{GTG})_{5}$ rep-PCR fingerprinting analyses. The morphologies of the isolates on PDA, YES agar, MEA, and $\mathrm{OA}$ were mostly similar in terms of the color and texture among them, with the exception of two isolatesone with a lighter color (KP52) and the other (KP14) with an irregular growth pattern. Gillot et al. (11) have reported a high morphological diversity of $P$. roqueforti. In that study, the researchers collected 120 blue-veined cheeses from 18 different countries in addition to some non-cheese substrates to create a $P$. roqueforti collection. High morphological diversity was observed (nine morphotypes) and the most distinctive colors were observed on PDA, with color differences between light to dark greenish-gray and a texture from velvety to fascicular. In the present study, isolates were not as diverse as those in the Gillot et al. (11) study, most likely because only one cheese type was used.

The genetic diversity of P. roqueforti isolates has been investigated in a number of studies. For example, studies using random amplified polymorphic DNA PCRbased fingerprinting using several primers revealed very similar banding patterns among different $P$. roqueforti isolates, which indicated high genetic similarity; however, different strains can be differentiated $(4,9)$. Studies conducted using developed microsatellite markers allowed the different $P$. roqueforti populations throughout the world to produce and identify different types of blue cheeses $(11,26)$. The most recent study (7) analyzed the genomes of $P$. roqueforti isolates from different origins and found four genetically differentiated populationsRoquefort cheese isolates, non-Roquefort blue cheese isolates, silage and food spoiler group, and woodassociated isolates with other food spoilers.

In the present study, we used repetitive sequencebased PCR to analyze genetic diversity, which is also very useful for bacteria as well as fungal fingerprinting (24, $31)$. This technique has never been used on $P$. roqueforti. Similar to the results of previous RAPD-based studies, we observed very similar electrophoresis band patterns among the $P$. roqueforti isolates with the exception of one (KP53), which clearly showed a reproducible different pattern. The similarity of 52 out of the 53 isolates might indicate the presence of a specific strain that inhabits the cellars/rooms/caves used for Kuflu cheese ripening and that passes through the cheeses to create a nearly uniform population; however, there might be different genotypes that we were not able to identify using $(\mathrm{GTG})_{5}$. The morphologically different isolates (KP52 and KP14) had the commonly observed (GTG) 5 pattern among the isolates; therefore, they could not be genotypically differentiated. Additional studies using different primers or more sophisticated techniques, such as whole-genome comparisons, might provide further information on genetic diversity.

In conclusion, in the present study, 53 of 54 filamentous fungal isolates of Konya Kuflu Tulum cheese were identified as $P$. roqueforti. In addition, 8 yeast isolates were identified as $P$. membranifaciens, $C$. zeylanoides, D. hansenii, and G. candidum. With the exception of two isolates, all $P$. roqueforti isolates had similar morphologies. In addition, $(\mathrm{GTG})_{5}$ fingerprinting of $P$. roqueforti isolates revealed a nearly identical pattern for all except one isolate. In future studies, a comparison among Konya Kuflu cheese isolates and other isolates of Turkish mold-ripened cheeses, such as Erzurum Kuflu Civil, Kars Kuflu Civil, and Divle cave cheese, and among blue cheese starter strains used throughout the world would help to understand the factors that make these different types of blue cheeses unique.

\section{Finacial Support}

This study was funded by the Scientific and Technological Research Council of Turkey (TUBITAK), grant number 1190314 to Banu Metin.

\section{Ethical Statement}

This study does not present any ethical concerns. 


\section{Conflict of Interest}

The authors declared that there is no conflict of interest.

\section{References}

1. Álvarez-Martín P, Flórez AB, López-Díaz TM, et al (2007): Phenotypic and molecular identification of yeast species associated with Spanish blue-veined Cabrales cheese. Int Dairy J, 17, 961-967.

2. Albenzio M, Corbo M, Rehman S, et al (2001): Microbiological and biochemical characteristics of Canestrato Pugliese cheese made from raw milk, pasteurized milk or by heating the curd in hot whey. Int $\mathrm{J}$ Food Microbiol, 67, 35-48.

3. Belén Flórez A, Álvarez-Martín P, López-Díaz TM, et al (2007): Morphotypic and molecular identification of filamentous fungi from Spanish blue-veined Cabrales cheese, and typing of Penicillium roqueforti and Geotrichum candidum isolates. Int Dairy J, 17, 350-357.

4. Boysen M, Skouboe P, Frisvad J, et al (1996): Reclassification of the Penicillium roqueforti group into three species on the basis of molecular genetic and biochemical profiles. Microbiology, 142, 541-549.

5. Cantor MD, van den Tempel T, Hansen TK, et al (2004): Blue cheese. 175-198. In: Fox PF, McSweeney PLH, Cogan TM, Guinee TP (Eds), Cheese: Chemistry, Physics and Microbiology, Academic Press, London.

6. Demirer MA (1974): A study of molds isolated from certain cheeses and their ability to produce aflatoxins. Ankara Univ Vet Fak Derg, 21, 180-198.

7. Dumas E, Feurtey A, Rodríguez de la Vega RC, et al (2020): Independent domestication events in the bluecheese fungus Penicillium roqueforti. Mol Ecol, 29, 26392660 .

8. Frisvad JC, Samson RA (2004): Polyphasic taxonomy of Penicillium subgenus Penicillium. A guide to identification of food and air-borne terverticillate Penicillia and their mycotoxins. Stud Mycol, 49, C174.

9. Geisen R, Cantor M, Hansen T, et al (2001): Characterization of Penicillium roqueforti strains used as cheese starter cultures by RAPD typing. Int J Food Microbiol, 65, 183-191.

10. Glass NL, Donaldson GC (1995): Development of primer sets designed for use with the PCR to amplify conserved genes from filamentous ascomycetes. Appl Environ Microbiol, 61, 1323-1330.

11. Gillot G, Jany J-L, Coton M, et al (2015): Insights into Penicillium roqueforti morphological and genetic diversity. PloS One, 10, e0129849.

12. Gillot G, Jany J-L, Poirier E, et al (2017): Functional diversity within the Penicillium roqueforti species. Int $\mathrm{J}$ Food Microbiol, 241, 141-150.

13. Gripon JC (1993): Mould-Ripened Cheeses. 111-136. In: PF Fox (Ed), Cheese: Chemistry, Physics and Microbiology, Springer, Boston.

14. Guley Z, Uysal H, Kilic S (2015): Lactic acid bacteria flora of Konya kuflu cheese: a traditional cheese from Konya province in Turkey. J Microbiol Biotechnol Food Sci, 04, 238-242.

15. Harrigan W (1998): Laboratory Methods in Food Microbiology. Academic Press, San Diego.
16. Hayaloglu AA, Kirbag S (2007): Microbial quality and presence of moulds in Kuflu cheese. Int J Food Microbiol, 115, 376-380.

17. Healy M, Huong J, Bittner T, et al (2005): Microbial DNA typing by automated repetitive-sequence-based PCR. J Clin Microbiol, 43, 199-207.

18. Kimura M (1980): A simple method for estimating evolutionary rates of base substitutions through comparative studies of nucleotide sequences. J Mol Evol, 16, 111-120.

19. Kumar S, Stecher G, Li M, et al (2018): MEGA $X$ : Molecular evolutionary genetics analysis across computing platforms. Mol Biol Evol, 35, 1547-1549.

20. Metin B (2018): Filamentous Fungi in Cheese Production. 257-275. In: Ş Öztürkoğlu Budak, HC Akal (Eds). Microbial Cultures and Enzymes in Dairy Technology. IGI Global, Hershey.

21. Ozmen Togay S, Capece A, Siesto G, et al (2020): Molecular characterization of yeasts isolated from traditional Turkish cheeses. Food Sci Technol, 40, 871-876.

22. Ozturkoglu Budak S, Figge MJ, Houbraken J, et al (2016): The diversity and evolution of microbiota in traditional Turkish Divle Cave cheese during ripening. Int Dairy J, 58, 50-53.

23. Özkalp B, Durak Y (1998): Investigation of mold flora in moldy cheeses of Konya and its vicinity. Turk J Biol, 22, 341-346.

24. Redondo C, Cubero J, Melgarejo P (2009): Characterization of Penicillium Species by Ribosomal DNA Sequencing and BOX, ERIC and REP-PCR Analysis. Mycopathologia, 168, 11.

25. Ridgway R (1912): Color standards and color nomenclature. The author, Washington, D.C.

26. Ropars J, López-Villavicencio M, Dupont J, et al (2014): Induction of sexual reproduction and genetic diversity in the cheese fungus Penicillium roqueforti. Evol Appl, 7, 433441.

27. Tekinşen KK, Cebirbay MA, EImalı M (2009): Moldy cheese of Konya. Akademik Gida, 7, 31-35.

28. Turin, Riva, Galbiati, et al (2000): Fast, simple and highly sensitive double-rounded polymerase chain reaction assay to detect medically relevant fungi in dermatological specimens. Eur J Clin Invest, 30, 511-518.

29. Ünsal A (1997): Süt Uyuyunca - Türkiye Peynirleri. Yap1 Kredi Yayınları, İstanbul.

30. Van den Tempel T, Jakobsen M (2000): The technological characteristics of Debaryomyces hansenii and Yarrowia lipolytica and their potential as starter cultures for production of Danablu. Int Dairy J, 10, 263270.

31. Versalovic J, Schneider M, Bruijn FJ, et al (1994): Genomic fingerprinting of bacteria using repetitive sequence-based polymerase chain reaction. Methods Mol Cell Biol, 5, 25-40.

32. Visagie CM, Houbraken J, Frisvad JC, et al (2014): Identification and nomenclature of the genus Penicillium. Stud Mycol, 78, 343-371.

33. Yalcin S, Senses S, Ozbas Y (2012): Identification and enzymatic characterization of the yeasts isolated from Erzincan tulum cheese. Mljekarstvo, 62, 53-61. 